\title{
PROTECTIVE EFFECT OF ATRIPLEX HALIMUS EXTRACT AGAINST BENZENE-INDUCED HAEMATOTOXICITY IN RATS
}

\author{
K. ZEGHIB ${ }^{1 \bowtie}$, D. A. BOUTLELIS², S. MENAI ${ }^{3}$, M. DEBOUBA ${ }^{4}$ \\ ${ }^{1}$ Department of Chemistry, Faculty of Exact Sciences, University of El-Oued, El-Oued, Algeria; \\ ${ }^{2}$ Department of Biology, Faculty of Natural Sciences and Life, University of El-Oued, El-Oued, Algeria; \\ ${ }^{3}$ The Mother-Child Hospital (Bachir Bennacer) of El-Oued, El-Oued, Algeria; \\ ${ }^{4}$ Higher Institute of Applied Biology of Medenine, University of Gabès, Tunisia; \\ 凶e-mail: zeghib-khaoula@univ-eloued.dz
}

Received:24 December 2020; Accepted: 07 July 2021

\begin{abstract}
Benzen (BZ) is a ubiquitous environmental pollutant with a toxic effect mainly aimed at the hematopoietic and immune systems. Atriplex halimus L. (Amaranthaceae) is a Mediterranean halophytic shrub traditionally used in North Africa as medicinal plant for several therapeutic uses. The present study aimed to estimate the preventive and curative effects of Atriplex halimus L. (Ah) aqueous extract against BZ-induced hematotoxicity in rats. Analysis of the extract by the method of LC-MS revealed the presence of 7 vitamins, among which vitamin C content was the highest. Adult rats were divided into five groups as follow: Group 1 received water (control); Group 2 received orally Ah aqueous extract (200 mg/kg) 3 days/week for 15 weeks; Group 3 received BZ (100 mg/kg b.w) daily in drinking water for 15 weeks; Group 4 received concomitantly BZ (100 mg/ $\mathrm{kg}$ ) and preventive treatment with $\mathrm{Ah}(200 \mathrm{mg} / \mathrm{kg})$ for 15 weeks (AhP+BZ); Group 5 first received BZ (100 mg/ $\mathrm{kg}$ ) for 11 weeks and then curative treatment with Ah extract $(300 \mathrm{mg} / \mathrm{kg})$ daily for 30 days $(B Z+A h C)$. It was shown that sub-chronic exposure to benzene induced leukopenia, lymphocytopenia, granulocytopenia and massive degeneration of the bone marrow tissue. The level of GSH and activity of GST and CAT were signifcantly lowered and the level of MDA was increased in the blood and bone marrow in rats of BZ-intoxicated group compared to the control rats. Administration of Ah extract recovered the bone marrow structure, dramatically decreased MDA content and increased GSH and CAT activity and GST level in the blood and bone marrow as compared with the indices in BZ-treated group. These observations demonstrate that curative and, to a lesser extent, preventive treatment with Atriplex halimus extract have therapeutic potential against hematotoxicity induced by benzene.
\end{abstract}

Ke y w ord s: Atriplex halimus, benzene, haematotoxicity, leukopenia, oxidative stress, bone marrow.

$\mathrm{X}$ enobiotics such as drugs, food additives and environmental pollutants are foreign chemical compounds to our biological system [1]. Many of these compounds are responsible for induction and development of many diseases [2]. Benzene (BZ) is a ubiquitous environmental pollutant; it has been classified as a group 1A carcinogen [3]. The primary target organs for benzene toxicity are the hematopoietic and immune systems. Chronic exposure to low levels of benzene produces toxic effects principally in the blood and blood-forming tissues [4]. Benzene is a potent bone marrow toxin and car- cinogen [5]. Anaemia, leukopenia, thrombocytopenia, marrow hyperplasia, acute myeloid leukaemia and chronic lymphocytic leukaemia have all been reported after chronic benzene exposure [3]. Everyone is exposed to a small amount of benzene every day [6]. The general population is exposed to benzene in the atmosphere by inhalation of vapours released by motor vehicles, gasoline service stations, cigarette smoke or by ingestion of polluted foods or water [3-7].

Although many xenobiotics have been banned, they continue to exert their effect, which is why they 
continue to be a focus of current researches. Therefore, many efforts have been made recently for discovering new products of natural origin, which can use for treatment and/or prevention of several diseases and unfavourable health effects of exposure to xenobiotics [8-9]. Plants have a great potential for producing new drugs of large benefit to mankind. It has played a central part in the treatment and prevention of human diseases during thousands of years [10].

Atriplex halimus L. is a halophyte shrub belonging to the Chenopodiaceae family [11], commonly known as Guetaf. [12]. It has a good nutritive and energetic value as a food for humans and as livestock forage [13]. In traditional medicine, A. halimus is widely used for several therapeutic uses [14]. This plant was used to treat heart disease, diabetes, rheumatism [15], urinary tract inflammation (cystitis), and to cure stomach pains and for intestinal worms [12]; it accompanies any diet that requires tissue drainage and desincrustation of wastes and toxins [13]. In Algeria, A. halimus is mainly used by the local population as a remedy to treat cancer [16], diabetes mellitus and anaemia [17].

Given these considerations, the objective of our study was to investigate the possible preventive and curative effects of the aqueous extract of Atriplex halimus L against BZ-induced haematotoxicity and immunotoxicity in Wistar rats.

\section{Materials and Methods}

Plant material. A. halimus L. aerial parts were collected in September 2017 from Biskra state, Algeria; and were identified by the botanist at the herbarium in the Center for Scientific and Technical Research on Arid Regions (CRSTRA) of Biskra, Algeria. The plant material was washed using water, dried at room temperature, and grounded into powder and then stored at room temperature until use.

Preparation of aqueous extract. About $10 \mathrm{~g}$ of the aerial parts powder of Ah was soaked in $100 \mathrm{ml}$ of distilled water and kept at room temperature in the dark for $24 \mathrm{~h}$. Then, it was filtered through filter paper. After extraction, the solvent was removed using a rotary evaporator and incubated at $40^{\circ} \mathrm{C}$ to dry completely. The extract was weighed and stored in a refrigerator at $4^{\circ} \mathrm{C}$ for future analysis [18].

Phytochemical screening. Polyphenols, flavonoids [19], cardiac glycosids, saponins [20], steroids and terpenes, mucilage [21], anthocyanins [22], alkaloids [23], tannins [24], carotenoids [25], and cou- marins [26] were identified using classical methods in the aqueous extract of Atriplex halimus.

Quantification of vitaminic compounds by $L C$ MS technique. The analysis for phenolic compounds was performed on a Shimadzu UFLC XR system (Kyoto, Japan), equipped with a SIL-20AXR autosampler, a CTO-20 AC column oven, a LC-20ADXR binary pump and a quadripole 2020 detector system. LC-ESI (-) MS mass spectra [M-H]- were acquired using LabSolutions software. Vitaminic compounds were identified by comparison with the retention time of the standards.

In vivo study. Male Wistar albino rats were obtained from the animal house of Pasteur Institute, Algeria, and were kept in the animal house of Molecular and Cellular Biology Department, University of El-Oued, Algeria. Rats were maintained under the standard laboratory conditions and standard rat food and potable water were available ad libitum for the duration of the experiments. The animal experiments in the present study were performed according to the National Institute of Health Guidelines for Animal Care and approved by the Ethics Committee of our Institution ( $\left.{ }^{\circ} 30 \mathrm{CMB} / 130 / 2020\right)$.

30 adult albino rats, weighing $224.98 \pm 3.81 \mathrm{~g}$, were divided into five groups of six rats as follow: Group 1 were received normal water (control); Group 2 were treated orally by gavage $200 \mathrm{mg} / \mathrm{kg}$, b.w (3 days/week) of Atriplex halimus L (Ah) aqueous extract for 15 weeks; Group 3 were administered $100 \mathrm{mg} / \mathrm{kg}$, b.w/day of benzene (BZ) daily in drinking water for 15 weeks; Group 4 were concomitantly received preventively Ah 200) mg/kg, 3 days/ week) with BZ (100 mg/kg) for 15 weeks (AhP+BZ); Group 5 were firstly administered BZ $(100 \mathrm{mg} / \mathrm{kg})$ only for 11 weeks then treated curatively by $300 \mathrm{mg} /$ kg, b.w/day of Ah (BZ+AhC) for 30 days.

Samples preparation. Blood collection. At the end of the study, rats were fasted for $16 \mathrm{~h}$, after that, sacrificed by cervical dislocation under chloroform anaesthesia. Blood was collected from all the animals and was used immediately for the complete blood count test (CBC) blood samples and for cytopathological examination. Then, the blood was frozen at $-20^{\circ} \mathrm{C}$ for oxidative stress parameters analysis.

Femurs collection and bone marrow sampling. The femurs and tibias were collected and cleansed from muscles. One femur bone of animal of each group was fixed in formaldehyde (10\%) for histopathological examination. Then, a small plug of marrow is gently extracted and smeared on glass slides 
for cytopathological examination. Then, all the marrows were removed from the femurs and were stored at $-20^{\circ} \mathrm{C}$ for oxidative stress parameters analysis [27].

Haematological parameters analysis. Haematological analysis was performed using an automatic haematological analyser Medonic (Coulter Beckman, USA). The parameters included: white blood cell (WBC) count, lymphocytes and granulocytes counts.

Oxidative stress parameters. Preparation of homogenates. Homogenates (10\%) were prepared by homogenizing the tissue samples in TBS buffer solution (Tris $50 \mathrm{mM}, \mathrm{NaCl} 150 \mathrm{mM}$; pH 7.4) and centrifuging the homogenates at $0^{\circ} \mathrm{C}$; $4000 \mathrm{rpm}$ for $45 \mathrm{~min}$. The supernatants were collected and preserved at $-20^{\circ} \mathrm{C}$ for oxidative stress markers. The protein content in each homogenate was estimated according to Bradford method using bovine serum albumin as a standard [28].

Estimation of malondialdehyde level. Malondialdehyde (MDA) level was determined by the method described by Quintanilha (1981) and expressed as nmol of MDA/mg protein [29].

Determination of reduced glutathione level. GSH concentration was performed with the method described by Ellman (1959) based on the development of yellow colour. Total GSH content was expressed as nmol GSH/mg protein [30].

Determination of Glutathione-S-transferase activity. GST activity was performed using the method of Habig et al. (1974). GST activity was calculated in terms of nmol CDNB-GSH conjugate formed $/ \mathrm{min} / \mathrm{g}$ tissue [31].

Determination of catalase activity. CAT activity was estimated according to Aebi (1984) method. The enzymatic activity was expressed in terms of international unit per minute and per gram of protein (IU/min/g of protein) [32].

Histopathological examination. Femur bone were dehydrated in ascending graded series of ethanol, cleaned with toluene. The samples embedded in paraffin blocks and thin sectioning was performed according to paraffin slice techniques. The sections were further mounted on to the microscopic slides and stained with Hematoxylin and Eosin stains. These microscopic slides were observed under the light microscope.

Statistical analysis. Data were expressed as mean \pm SD of six animals. Statistical analysis was carried out by using Student $t$-test to compare means between two groups. Results were evaluated using the Minitab and EXCEL software. Differences were considered significant at $P \leq 0.05$.

\section{Results}

Phytochemical study of aqueous extract of Atriplex halimus $L$.Phytochemical analysis revealed the presence of polyphenols, steroids, terpenes, flavonoids, anthocyanins, tannins, alkaloids, saponins, cardiac glycosides, coumarins and mucilage in the aqueous extract of $A$. halimus $\mathrm{L}$.

LC-MS vitaminic compounds of aqueous extract of A. halimus. Among eight vitamins analyzed, 7 compounds were detected and quantified in this plant (Table 1): Vitamins $\mathrm{B}_{1}, \mathrm{~B}_{3}, \mathrm{~B}_{6}, \mathrm{~B}_{5}, \mathrm{~B}_{7}, \mathrm{~B}_{12}$, C.

Haematological parameters. Analysis of total leucocytes count and differential leucocytes count showed that exposure to benzene results in a huge decline in total leucocyte, lymphocyte and granulocyte counts which revealed a leukopenia, lymphocytopenia and granulopenia in benzene rats (Fig. 1). Meanwhile, Ah curative treatment (BZ+AhC) made a recovery in these parameters, but no ameliorating

Ta b le 1. LC-MS/MS data of vitamins in aqueous extract of A. halimus

\begin{tabular}{clccc}
\hline ID\# & Name & Ret. Time & $\mathrm{m} / \mathrm{z}$ & Conc. $\mu$ g/g dry extract \\
\hline 1 & Thiamine (vitamin $\mathrm{B}_{1}$ ) & 2.776 & 265.00 & 36.833 \\
2 & Niacin (vitamin $\mathrm{B}_{3}$ ) & 3.717 & 124.00 & 27.964 \\
3 & Pyridoxine (vitamin $\mathrm{B}_{6}$ ) & 4.595 & 170.00 & 1.142 \\
4 & Pantothenic acid (vitamin $\mathrm{B}_{5}$ ) & 9.981 & 220.00 & 65.071 \\
5 & Cyanocobalamin (vitamin $\mathrm{B}_{12}$ ) & - & 679.00 & N.D.(Peak) \\
6 & Biotin (vitamin $\mathrm{B}_{7}$ ) & 12.445 & 245.00 & 104.263 \\
7 & Riboflavin (vitamin $\mathrm{B}_{2}$ ) & 12.145 & 377.00 & 55.228 \\
8 & Ascorbic acid L (vitamin C) & 2.065 & 177.00 & 477.569 \\
\hline
\end{tabular}



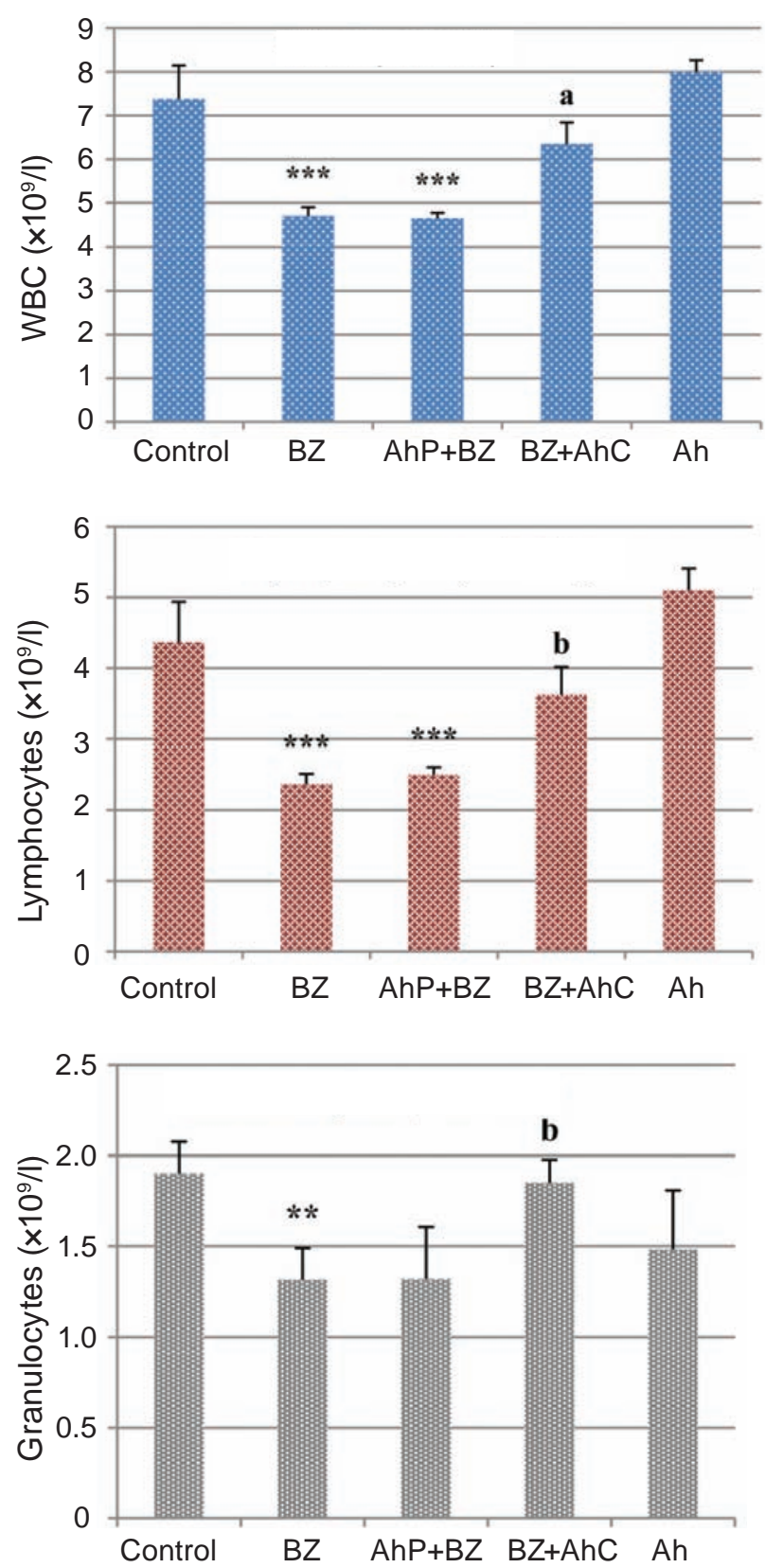

Fig. 1. Total white blood cells, lymphocytes and granulocytes counts in peripheral blood of control and experimental groups. Values are mean $\pm S D$, six rats in each group. For Student's t-test significant $P$ value $A h, B Z, B Z+A h C$, and $A h P+B Z$ versus control $* * P \leq 0.01, * * * P \leq 0.001$ and therapy versus $B Z$ ${ }^{a} P \leq 0.05,{ }^{b} P \leq 0.01$

effect observed for preventive treatment (AhP+BZ). On the other hand, Atriplex halimus alone did not significantly affect these parameters.

Oxidative stress parameters. Blood. Table 2 shows the lipid peroxidation index (MDA), and nonenzymatic (GSH) and enzymatic antioxidant (GST,
CAT) parameters in peripheral blood. Benzene administration at $100 \mathrm{mg} / \mathrm{kg}$ to rats caused a significant $(P \leq 0.01)$ increase in MDA level; and caused a significant decrease in GSH $(P \leq 0.05)$ concentration, CAT $(\mathrm{p} \leq 0.001)$ and GST $(P \leq 0.01)$ activities as compared to control group. Administration of A. halimus aqueous extract alone to rats had no significant effect on the oxidative stress parameters as compared to untreated rats. On the other hand, co-administration of A. halimus to benzene exposed animals alleviated lipid peroxidation and significantly attenuated the decrease in catalase and GST activities, but no ameliorating effect in GSH levels. However, curative treatment with Ah restored these parameters to the control values.

Bone marrow. Data concerning oxidative stress status in the bone marrow are presented in Table 2 The MDA level was significantly increased in benzene intoxicated rats when compared with control group. The antioxidant status was impaired by benzene exposure, which shown by the lowest values of GSH and severe reduction in GST and catalase activities. In contrast, treatments of BZ rats with either AhP or AhC dramatically improved the antioxidant status and attenuated the increase of lipid peroxidation level of bone marrow tissues as compared to BZ group. In addition, treatment with the plant extract alone caused a significant decreased in $(P \leq 0.001)$ MDA and $(P \leq 0.05)$ GSH levels.

Histopathological studies. Histological examination of femoral bone of control and Ah treated rat showed normal histological architecture of bone marrow, which consists of normal hematopoietic tissue and adipose cells surrounded by vascular sinuses and interspersed within a normal meshwork of trabecular bone (Fig. 2, Ca, Cb, Ah). However, the section of BZ exposed rat showed a large deterioration of hematopoietic tissue with deposition of dense fibrous tissue, haemorrhage, dispersed inflammatory infiltrate, vascular and intercellular oedema, congested vessels and irregular areas of bone marrow formation (Fig. 2, BZa, BZb, BZc). On the other hand, in group treated curatively by A. halimus the bones marrows were recovered to structure near to that of control (Fig. 2, AhC+BZ); while moderate restoration was showed in $\mathrm{AhP}+\mathrm{BZ}$ group (Fig. 2, AhP+BZ).

Histopathological changes are graded and summarized in Table 3. Histological grading was made according to four severity grades: - (none); + (mild); ++ (moderate) and +++ (severe). 
Ta b le 2. Oxidative stress parameters in blood and bone marrow of control and experimental groups

\begin{tabular}{lcccccc}
\hline \multicolumn{1}{c|}{ Parameters } & Control & BZ & AhP+BZ & BZ+AhC & Ah \\
\hline $\begin{array}{l}\text { GSH, } \\
\text { nmol/mg protein }\end{array}$ & $11.18 \pm 0.56$ & $10.08 \pm 0.35^{*}$ & $9.66 \pm 0.38^{*}$ & $11.26 \pm 0.44^{\mathrm{a}}$ & $10.55 \pm 0.87$ \\
$\begin{array}{l}\text { MDA, } \\
\text { nmol/mg protein }\end{array}$ & $21.27 \pm 0.82$ & $26.41 \pm 1.18^{* *}$ & $23.46 \pm 1.15^{\mathrm{a}}$ & $22.95 \pm 0.86^{\mathrm{b}}$ & $22.11 \pm 0.92$ \\
$\begin{array}{l}\text { Catalase, } \\
\times 10^{3} \text { U/g protein }\end{array}$ & $0.73 \pm 0.05$ & $0.47 \pm 0.03^{* * *}$ & $0.75 \pm 0.06^{\mathrm{c}}$ & $0.67 \pm 0.05^{\mathrm{b}}$ & $0.79 \pm 0.05$ \\
$\begin{array}{l}\text { GST, } \\
\text { nmol/mg protein }\end{array}$ & $0.56 \pm 0.02$ & $0.40 \pm 0.04^{* *}$ & $0.52 \pm 0.04^{\mathrm{a}}$ & $0.65 \pm 0.06^{\mathrm{b}}$ & $0.55 \pm 0.05$ \\
& \multicolumn{3}{c}{ Bone marrow } & \\
$\begin{array}{l}\text { GSH, } \\
\text { nmol/mg protein }\end{array}$ & $603.4 \pm 28.2$ & $517.0 \pm 29.9^{*}$ & $626.4 \pm 38.7^{\mathrm{a}}$ & $540.7 \pm 32.3$ & $550.5 \pm 12.6^{*}$ \\
$\begin{array}{l}\text { MDA, } \\
\text { nmol/mg protein }\end{array}$ & $12.46 \pm 0.62$ & $14.89 \pm 1.09^{*}$ & $7.26 \pm 0.90 * * *, \mathrm{c}$ & $12.71 \pm 0.81^{\mathrm{a}}$ & $8.82 \pm 0.79^{* * *}$ \\
$\begin{array}{l}\text { Catalase, } \times 10^{3} \\
\text { U/g protein }\end{array}$ & $0.09 \pm 0.01$ & $0.05 \pm 0.01^{* * *}$ & $0.10 \pm 0.01^{\mathrm{b}}$ & $0.12 \pm 0.01^{\mathrm{c}}$ & $0.09 \pm 0.01$ \\
$\begin{array}{l}\text { GST, } \\
\text { nmol/mg protein }\end{array}$ & $41.53 \pm 3.43$ & $16.05 \pm 3.83^{* * *}$ & $36.56 \pm 5.33^{\mathrm{a}}$ & $40.06 \pm 6.19^{\mathrm{b}}$ & $39.63 \pm 4.65$ \\
\hline
\end{tabular}

Values are mean $\pm \mathrm{SD}$, six rats in each group. For Student's $t$-test significant $\mathrm{p}$ value $\mathrm{Ah}, \mathrm{BZ}, \mathrm{BZ}+\mathrm{AhC}$, and AhP+BZ versus control $* P \leq 0.05,{ }^{*} P \leq 0.01, * * * P \leq 0.001$ and therapy versus $\mathrm{BZ}{ }^{\mathrm{a}} P \leq 0.05,{ }^{\mathrm{b}} P \leq 0.01,{ }^{\mathrm{c}} P \leq 0.001$.

\section{Discussion}

Haematopoietic system is a critical target for benzene toxicity [7]. Epidemiological researches have shown that exposure to benzene can result in a variety of blood and bone marrow disorders [33]. In our study, sub-chronic exposure to benzene induced leukopenia, lymphocytopenia and granulocytopenia in Wistar albino rats. Our findings were supported by other experiments in which reported that leukopenia is the most haematological change associated with benzene exposure [34-36]. Also, Irons et al. [37] and Rothman et al. [38] reported that lympho- cyte is the most sensitive cell line in the peripheral blood for monitoring the onset of benzene toxicity in rats. Then, neutropenia was evident in employees of the steel plant of Cubatiio after environmental contamination with benzene in a study conducted by Ruiz et al. [39].

This haematological deficiency can be explained by alteration of bone marrow functions, suggesting that benzene interferes with haematopoiesis process. Indeed, benzene and its metabolites can affect haematopoietic progenitor cells at intermediate stages of differentiation, proliferation and/or maturation, leading to a depression on bone marrow.

Table 3. Semi-quantitative recording of architectural damage on histopathological analysis of the bone marrow of control and treated rats $(n=6)$

\begin{tabular}{l|c|c|c|c|c}
\hline \multicolumn{1}{c|}{ Parameters } & Control & Ah & BZ & AhP+BZ & BZ+AhC \\
\hline Fibrosis & - & - & +++ & - & - \\
Inflammation & - & - & ++++ & - & - \\
Degeneration hematopoietic tissue & - & - & ++++ & - & - \\
Hypocellularity & - & - & ++ & - & - \\
Congestion and oedema & - & - & ++++ & - & - \\
Haemorrhage & - & - & +++ & - & - \\
\hline
\end{tabular}



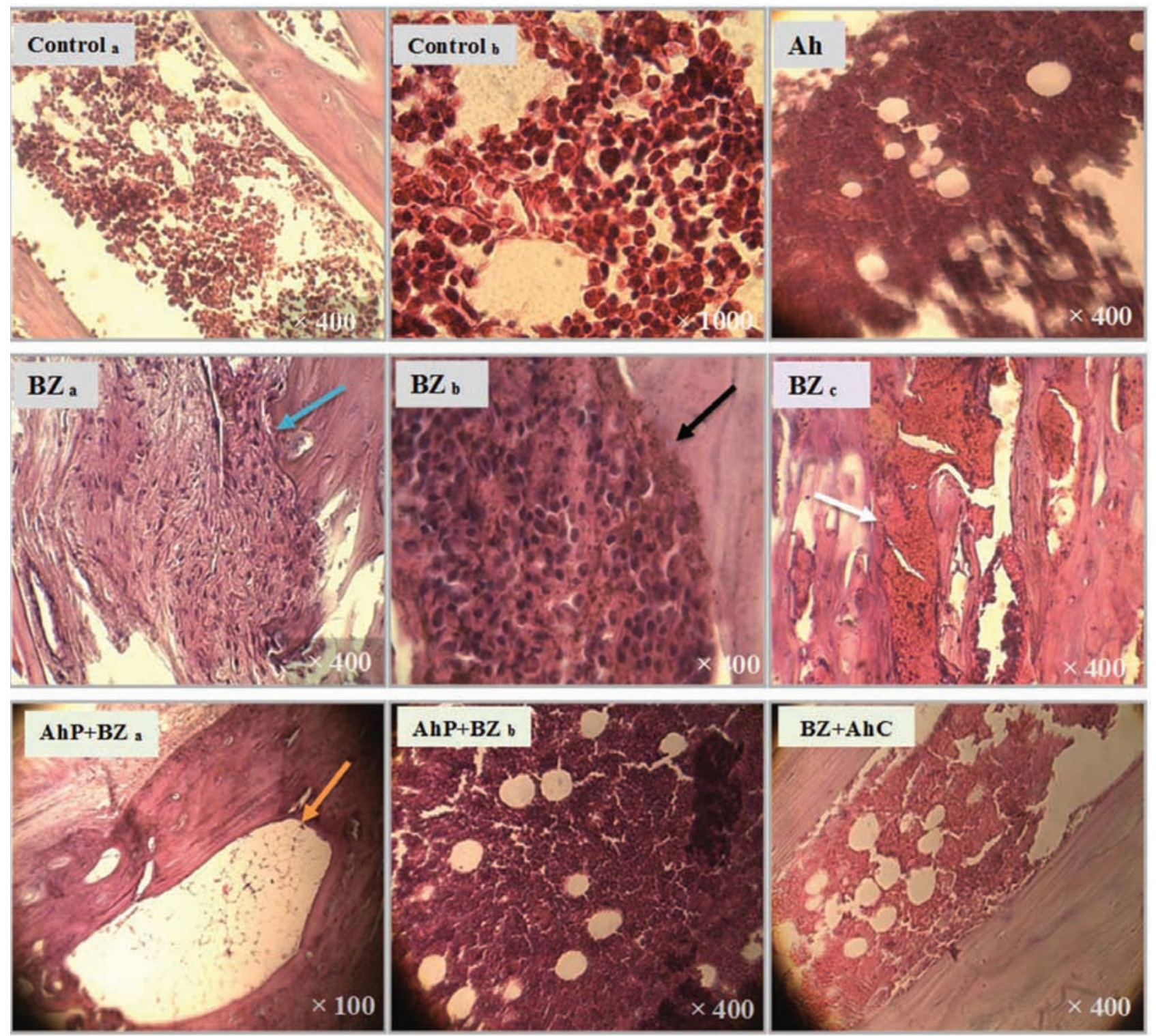

Fig. 2. Bone marrow section from Control and Ah group showing normal architecture; BZ group showing a fibrous tissue (BZ a, blue arrow), necrosis (BZ b, black arrow), haemorrhage (BZ $\boldsymbol{c}$, white arrow); $A h P+B Z$ group showing normal architecture $(A h P+B Z$ a), large adipocytes and hypocellularity $(A h P+B Z$ b, orange arrow); $B Z+A h C$ group showing normal architecture (Hematoxylin \& Eosin stain; magnification $\times 1000$ Control $\boldsymbol{b}, \times 100 \mathrm{AhP}+\mathrm{BZ} \boldsymbol{a}$ and $\times 400$ for the others sections)

Conversely, Atriplex halimus L curative treatment has potential therapeutic effects against haematotoxicity and immunotoxicity induced by benzene, while low effect was shown in preventive treatment. This difference between curative and preventive effects is probably due that $A$. halimus does not have directly an inhibiting effect on benzene and its metabolites induced haematopoiesis alteration, but it has immunomodulatory effect by stimulation of proliferation and differentiation of hematopoietic progenitor cells. The beneficial effect of $\mathrm{Ah}$ is at- tributed to its bioactive compounds such as terpenes and saponins. In this regard, there is a large group of monoterpenes, which possess immunomodulatory properties. It has been shown that monoterpenes from Plantago species increased the activity of human lymphocyte proliferation and secretion of interferon gamma, and also increase the WBC count in mice [40]. In addition, saponins can stimulate the cell-mediated immune system as well as to enhance antibody production [41]. 
Recent studies reported that BZ-initiated toxicity has been linked to oxidative stress [42]. More specifically, BZ can be enzymatically bioactivated to reactive metabolites (phenol, catechol, hydroquinone, and benzoquinones) which can produce ROS, decreases antioxidant activity and hence increases oxidative [43].

The MDA is a major oxidation product of lipid peroxidation [44], Our data demonstrated that BZ administration caused a significant increase in MDA levels as compared to control group in the studied tissues. These results are in good agreement with Roy and Pillai [45] who reported that benzene exposure increased bone marrow MDA levels in albino rats. Moreover, occupational inhalation of benzene vapours in the petrol station induced a significant increase in blood MDA levels in a study conducted by Maksoud et al. [46].

Results from the present study demonstrate that the levels of endogenous antioxidants both enzymatic and non-enzymatic (GSH, GST and CAT) are significantly lowered in the BZ-intoxicated group compared to the control rats, which are supported by the findings of Maksoud et al. [46] and Ibrahim et al. [44].

A. halimus extract dramatically decreased MDA level and increased GSH, CAT, and GST levels in blood and bone marrow induced by a daily dose of BZ. These observations demonstrate the potential antioxidant effects of Ah against BZ-induced oxidative stress by both curative and preventive treatment. This finding is confirmed by the results of phytochemical composition of Ah, in which we found that Ah contains a large number of the antioxidant compounds. Phenolic acid, flavonoids, ascorbic acid, and coumarins have been shown to possess strong antioxidant activities [47-49]. Flavonoids have a direct role in scavenging reactive oxygen species, which can counteract lipid oxidation and improve the antioxidant enzymes activities, and decrease peroxide formation [50]. Then, vitamin $\mathrm{C}$ is a potent antioxidant and a cofactor for a family of biosynthetic and gene regulatory antioxidant enzymes [48]. Other data suggest that coumarins are able to block the activity of xanthine oxidase, lipoxygenase and myeloperoxidase [51].

Histopathological observation of bone marrow tissue from the BZ group confirmed the haematological and cytological results and showed clear signs of haematotoxicity. Severe distortion of bone marrow architecture represented as myelofibrosis, necrosis, inflammatory infiltration, oedema, vas- cular congestion, haemorrhage, and focal areas of transformed cells were observed in benzene rats. As a possible mechanism, it has been shown that benzene increase prostaglandin E2 level and stimulated their formation in bone marrow [52]. This mediator plays a critical role in guiding and governing various aspects of the inflammatory diseases and elicits vascular permeability and oedema formation [53]. Also, this damage may refer to increase levels of reactive oxygen intermediates produced by benzene metabolism and/or activation of macrophages in the bone marrow [54].

After treatment by A. halimus, most of the bone marrow was recovered to structure near to that of control with a moderate restoration of $\mathrm{AhP}+\mathrm{BZ}$ group, these could be due to the anti-inflammatory and anti-radical efficiency of A. halimus. Flavonoids and mucilages were considered as the potential therapeutic agent involved in inflammatory diseases. They have been shown to be effective inhibitors of prostaglandins and oedema formation through inhibition of gene expression of cyclooxygenase enzymes (COX-1, 2) [49]. In addition, the sesquiterpene-monoterpene has been shown to be a potent anti-inflammatory agent, which suppressed the production of prostaglandin E2 and NO in macrophages [55]. The antifibrotic effect of A. halimus found in the present study was in agreement with another study in which Sourour et al. [56] found that co-administration of vitamin $\mathrm{C}$ reduced area per cent of collagen deposition in rat tissue caused by benzene, suggesting that antifibrotic effect of vitamin $\mathrm{C}$ may be mediated by its antioxidant effect.

Conclusion. In light of the results obtained, it can be concluded that Atriplex halimus aqueous extract is very rich in bioactive compounds especially the antioxidants. Then, A. halimus mainly curative treatment has potential protective effects against hematotoxicity and immunotoxicity induced by benzene. Hence, this data suggests that A. halimus aqueous extract can be used as a hemato-protective and immuno-protective nutrient and as a useful method helping to protect populations at high risk of BZ chronic intoxication.

Conflict of interest. Authors have completed the Unified Conflicts of Interest form at http://ukrbiochemjournal.org/wp-content/uploads/2018/12/ coi_disclosure.pdf and declare no conflict of interest.

Funding. Experimental studies were performed within the research work of the Department of Biology of the University of El-Oued and in medical 
cooperation with the mother-child hospital (Bachir Bennacer) of El-Oued (state registration number 39000).

Acknowledgments. This work was supported by Faculty of Sciences of Nature and Life, University of El-Oued, Algeria. The first author is grateful to Dr. Derouiche Samir, head of department of cellular and molecular biology and lecturer at the Faculty of Natural and Life Sciences, University of El-Oued, for their constant support and guidance throughout the study.

\section{ЗАХИСНА ДІЯ ЕКСТРАКТУ ATRIPLEX HALIMUS ПРОТИ ІНДУКОВАНОЇ БЕНЗОЛОМ ГЕМАТОТОКСИЧНОСТІ В ЩУ РІВ}

\section{K. Zeghib ${ }^{1 \bowtie}$, D. A. Boutlelis ${ }^{2}$, S. Menai ${ }^{3}$, M. Debouba ${ }^{4}$}

${ }^{1}$ Department of Chemistry, Faculty of Exact Sciences, University of El-Oued, El-Oued, Algeria; ${ }^{2}$ Department of Biology, Faculty of Natural Sciences and Life, University of El-Oued, El-Oued, Algeria; ${ }^{3}$ The Mother-Child Hospital (Bachir Bennacer) of El-Oued, El-Oued, Algeria; ${ }^{4}$ Higher Institute of Applied Biology of Medenine, University of Gabès, Tunisia; 『e-mail: zeghib-khaoula@univ-eloued.dz

Бензен (BZ) $є$ поширеним забруднювачем навколишнього середовища 3 токсичною дією, спрямованою, головним чином, на кровотворну та імунну системи. Atriplex halimus L. (Amaranthaceae) ((Ah) - середземноморський галофітний чагарник, який традиційно використовується в Північній Африці як лікарська рослина. Метою дослідження було оцінити профілактичний та лікувальний потенціал водного екстракту Atriplex halimus L. (Ah) у подоланні індукованої бензолом гематотоксичності в щурів. Методом LC-MS в екстракті виявили наявність 7 вітамінів, серед яких вміст вітаміну С був найвищим. Дорослих щурів було розділено на п'ять груп: група 1 отримувала воду (контроль); група 2 отримувала перорально водний екстракт $\mathrm{Ah}$ (200 мг/кг) 3 дні на тиждень протягом 15 тижнів; група 3 отримувала BZ (100мг/кг) щодня у питній воді протягом 15 тижнів; група 4 отримувала одночасно BZ (100 мг/кг) та Ah (200 мг/ кг) профілактично протягом 15 тижнів (AhP + BZ); група 5 спочатку отримувала BZ (100 мг/ кг) протягом 11 тижнів, а потім лікування екстрактом Ah (300 мг/кг) щодня протягом 30 днів $(\mathrm{BZ}+\mathrm{AhC})$. Показано, що субхронічна дія бензолу сричиняла лейкопенію, лімфоцитопенію, гранулоцитопенію та масивну дегенерацію тканини кісткового мозку. У крові та кістковому мозку інтоксикованих бензолом щурів рівень ензимних і неензимних ендогенних антиоксидантів (GST, CAT та GSH) був значно зниженим, а рівень MDA підвищеним порівняно із щурами контрольної групи. Введення екстракту Аh дозволило відновити структуру кісткового мозку, значно знизити вміст MDA, підвищити активність GST і CAT та рівень GSH у крові та кістковому мозку порівняно з відповідними показниками у групі, яка отримувала BZ. Результати цього дослідження демонструють, що лікувальне та меншою мірою профілактичне застосування екстракту Atriplex halimus має терапевтичний потенціал проти індукованої бензолом гематотоксичності.

К лючов в слова: Atriplex halimus, бензол, гематотоксичність, лейкопенія, оксидативний стрес, кістковий мозок.

\section{References}

1. El-Demerdash FM, Tousson EM, Kurzepa J, Habib SL. Xenobiotics, Oxidative Stress, and Antioxidants. Oxid Med Cell Longev. 2018; 2018: 9758951.

2. Sears ME, Genuis SJ. Environmental determinants of chronic disease and medical approaches: recognition, avoidance, supportive therapy, and detoxification. J Environ Public Health. 2012; 012: 356798.

3. Falzone L, Marconi A, Loreto C, Franco S, Spandidos DA, Libra M. Occupational exposure to carcinogens: Benzene, pesticides and fibers (Review). Mol Med Rep. 2016; 14(5): 4467-4474.

4. WHO (World Health Organization). Benzene in Drinking-water. Background document for development of WHO Guidelines for DrinkingWater Quality. World Health Organization. 2003.

5. Oshiro Y, Balwierz PS, Witz G. Micronucleus formation in mouse bone marrow cells in vivo in response to trans, trans-muconaldehyde. Toxicol Lett. 2001; 121(3): 159-166.

6. ATSDR (Agency for Toxic Substances and Disease Registry). Benzene Overview. Public 
Health Service, U.S. Department of Health and Human Services, Atlanta, GA. 2015.

7. Wilbur SB, Keith S, Faroon O, Wohlers D. Toxicological profile for benzene. 2007.

8. Abdou RH, Saleh SY, Khalil WF. Toxicological and biochemical studies on Schinus terebinthifolius concerning its curative and hepatoprotective effects against carbon tetrachloride-induced liver injury. Pharmacogn Mag. 2015; 11(Suppl 1): S93-S101.

9. Borowska S, Brzóska MM. Chokeberries (Aronia melanocarpa) and Their Products as a Possible Means for the Prevention and Treatment of Noncommunicable Diseases and Unfavorable Health Effects Due to Exposure to Xenobiotics. Compr Rev Food Sci Food Saf. 2016; 15(6): 9821017.

10. Dar RA, Shahnawaz M, Qazi PH. General overview of medicinal plants: A review. $J$ Phytopharmacol. 2017; 6(6): 349-351.

11. Clauser M, Dall'Acqua S, Loi MC, Innocenti G. Phytochemical investigation on Atriplex halimus L. from Sardinia. Nat Prod Res. 2013; 27(20): 1940-1944.

12. Slama K, Boumendjel M, Taibi F, Boumendjel A, Messarah M. Atriplex halimus aqueous extract abrogates carbon tetrachloride-induced hepatotoxicity by modulating biochemical and histological changes in rats. Arch Physiol Biochem. 2020; 126(1): 49-60.

13. Nedjimi B, Guit B, Toumi M, Beladel B, Akam A, Daoud Y. "Atriplex halimus subsp. schweinfurthii (Chenopodiaceae) : Description, écologie et utilisations pastorales et thérapeutiques”. Fourrages. 2013; 216: 333-338.

14. Al-Senosy N, Abou-Eisha A, Ahmad E. In vitro Antiproliferation Effect of Atriplex halimus L. Crude Extract on Human Cell Lines by Induction of Apoptosis and G2/M phase Arrest. Egypt Acad J Biol Sci. 2018; 10(1): 115-126.

15. Parvez MK, Arbab AH, Al-Dosari MS, AlRehaily AJ, Alam P, Ibrahim KE, Alsaid MA, Rafatullah S. Protective effect of Atriplex suberecta extract against oxidative and apoptotic hepatotoxicity. Exp Ther Med. 2018; 15(4): 38833891.

16. Alves-Silva JM, Romane A, Efferth T, Salgueiro L. North African Medicinal Plants Traditionally Used in Cancer Therapy. Front Pharmacol. 2017; 8: 383.

17. Mohammedi Z. Resistance, Pharmacology Properties and Nutritional Value of a Shrub from Arid Environments Atriplex halimus. Res J Med Plant. 2016; 10(1): 10-18.

18. Murugan R, Parimelazhagan T. Comparative evaluation of different extraction methods for antioxidant and anti-inflammatory properties from Osbeckia parvifolia Arn. - An in vitro approach. J King Saud Univ Sci. 2014; 26(4): 267-275.

19. Lucien BG, Calixte B, Gilles KN, Yapi HF, Djaman Allico J, N'Guessan JD. Assessment of Acute and Subacute Toxicity of the Total Dichloromethane-Ethanol Extract of Morinda morindoides (Baker) Milne-Redh (ETDE) on Rats. Pharmacogn J. 2015; 7(6): 372-377.

20. Yenon AA. Acute toxicity and phytochemical screening of stem bark extracts of Entandrophragma angolense (Welw.) C. DC.(Meliaceae). Asian J Biomed Pharm Sci. 2014; 4(38): 67-70.

21. Fofie NBY, Kiendrebeogo M, Coulibaly K, Sanogo R, Kone-bamba D. Mineral Salt Composition and Secondary Metabolites of Ocimum gratissimum L., An Anti-hyperglycemic Plant. Nat Prod Chem Res. 2016; 4(5): 235.

22. Chaouche T, Haddouchi F, Bekkara FA. Phytochemical study of roots and leaves of the plant Echiumpycnanthum Pomel. Der Pharmacia Letter. 2011; 3(2): 1-4.

23. Khan AM, Qureshi RA, Ullah F, Gilani SA, Nosheen A, Sahreen S, Laghari MK, Laghari MY, Shafiq-Ur-Rehman, Hussain I, Murad W. Phytochemical analysis of selected medicinal plants of Margalla Hills and surroundings. $J$ Med Plants Res. 2011; 5(25): 6017-6023.

24. Bidie AP, N'Guessan BB, Yapo AF, N'Guessan JD, Djaman AJ. Activités antioxydantes de dix plantes medicinales de la pharmacopée ivoirienne. Sci Nat. 2011; 8(1-2): 1-11.

25. El Yahyaoui O, Ouaaziz NA, Guinda I, Sammama A, Kerrouri S, Bouabid B, El Bakkall M, Quyou A, Lrhorfi LA, Bengueddour R. Phytochemical screening and thin layer chromatography of two medicinal plants: Adansonia digitata (Bombacaceae) and Acacia raddiana (Fabaceae). J Pharmacogn Phytochem. 2017; 6(1): 10-15.

26. Firdouse S, Alam P. Phytochemical investigation of extract of Amorphophallus campanulatus tubers. Int J Phytomed. 2011; 3(1): 32.

27. Anjos-Afonso F, Bonnet D. Isolation, culture, and differentiation potential of mouse marrow 
stromal cells. Curr Protoc Stem Cell Biol. 2008; 7(1): 2B-3.

28. Bradford MM. A rapid and sensitive method for the quantitation of microgram quantities of protein utilizing the principle of protein-dye binding. Anal Biochem. 1976; 72(1-2): 248-254.

29. Quintanilha AT, Packer L, Davies JM, Racanelli TL, Davies KJ. Membrane effects of vitamin $\mathrm{E}$ deficiency: bioenergetic and surface charge density studies of skeletal muscle and liver mitochondria. Ann N Y Acad Sci. 1982; 393: 32-47.

30. Weckbecker G, Cory JG. Ribonucleotide reductase activity and growth of glutathionedepleted mouse leukemia L1210 cells in vitro. Cancer Lett. 1988; 40(3): 257-264.

31. Habig WH, Pabst MJ, Jakoby WB. Glutathione S-transferases. The first enzymatic step in mercapturic acid formation. J Biol Chem. 1974; 249(22): 7130-7139.

32. Aebi H. Catalase in vitro. Methods Enzymol. 1984; 105: 121-126.

33. Han W, Wang S, Li M, Jiang L, Wang X, Xie K. The protective effect of diallyl trisulfide on cytopenia induced by benzene through modulating benzene metabolism. Food Chem Toxicol. 2018; 112: 393-399.

34. Elsayed, ASI, Hegazi MA. Ameliorative effects of curcumin and green tea against gasolininhalation hematotoxicity. Int J Appl Biol Pharm Technol. 2016; 7(1): 1-18.

35. Qu Q, Shore R, Li G, Jin X, Chen LC, Cohen B, Melikian AA, Eastmond D, Rappaport SM, Yin S, Li H, Waidyanatha S, Li Y, Mu R, Zhang X, Li K. Hematological changes among Chinese workers with a broad range of benzene exposures. Am J Ind Med. 2002; 42(4): 275-285.

36. Avogbe PH, Ayi-Fanou L, Cachon B, Chabi N, Debende A, Dewaele D, Aissi F, Cazier F, Sanni A. Hematological changes among Beninese motor-bike taxi drivers exposed to benzene by urban air pollution. Afr J Environ Sci Technol. 2011; 5(7): 464-472.

37. Irons RD, Heck H, Moore BJ, Muirhead KA. Effects of short-term benzene administration on bone marrow cell cycle kinetics in the rat. Toxicol Appl Pharmacol. 1979; 51(3): 399-409.

38. Rothman N, Smith MT, Hayes RB, Li GL, Irons RD, Dosemeci M, Haas R, Stillman WS, Linet M, Xi LQ, Bechtold WE, Wiemels J, Campleman S, Zhang L, Quintana PJ, Titenko-
Holland N, Wang YZ, Lu W, Kolachana P, Meyer KB, Yin S. An epidemiologic study of early biologic effects of benzene in Chinese workers. Environ Health Perspect. 1996; 104(Suppl 6): 1365-1370.

39. Ruiz MA, Augusto LG, Vassallo J, Vigorito AC, Lorand-Metze I, Souza CA. Bone marrow morphology in patients with neutropenia due to chronic exposure to organic solvents (benzene): early lesions. Pathol Res Pract. 1994; 190(2): 151-154.

40. Brahmkshatriya PP, Brahmkshatriya PS. Terpenes: Chemistry, Biological Role, and Therapeutic Applications. Eds. Ramawat K, Mérillon JM. Natural Products. 2013: 26652691.

41. Rajput ZI, Hu SH, Xiao CW, Arijo AG. Adjuvant effects of saponins on animal immune responses. J Zhejiang Univ Sci B. 2007; 8(3): 153-161.

42. Badham HJ, Renaud SJ, Wan J, Winn LM. Benzene-initiated oxidative stress: Effects on embryonic signaling pathways. Chem Biol Interact. 2010; 184(1-2): 218-221.

43. Uzma N, Kumar BS, Hazari MA. Exposure to benzene induces oxidative stress, alters the immune response and expression of p53 in gasoline filling workers. Am J Ind Med. 2010; 53(12): 1264-1270.

44. Ibrahim KS, Saleh ZA, Farrag AR, Shaban EE. Protective effects of zinc and selenium against benzene toxicity in rats. Toxicol Ind Health. 2011; 27(6): 537-545.

45. Roy H, Pillai A. Evaluation of ROS induced genetic aberration in benzene intoxicated rat bone marrow. J Cell Tissue Res. 2015; 15(2): 4957.

46. Abdel Maksoud HA, Elharrif MG, Mahfouz MK, Omnia MA, Abdullah MH, Eltabey ME. Biochemical study on occupational inhalation of benzene vapours in petrol station. Respir Med Case Rep. 2019; 27: 100836.

47. Adegbola P, Aderibigbe I, Hammed W, Omotayo T. Antioxidant and anti-inflammatory medicinal plants have potential role in the treatment of cardiovascular disease: a review. Am J Cardiovasc Dis. 2017; 7(2): 19-32.

48. Carr AC, Maggini S. Vitamin C and Immune Function. Nutrients. 2017; 9(11): 1211.

49. Cicero AFG, Colletti A. Effects of Carotenoids on Health: Are All the Same? Results from Clinical Trials. Curr Pharm Des. 2017; 23(17): 2422-2427. 
50. Zou Z, Xi W, Hu Y, Nie C, Zhou Z. Antioxidant activity of Citrus fruits. Food Chem. 2016; 196: 885-896.

51. Filipsky T, Riha M, Macakova K, Anzenbacherová E, Karlickova J, Mladenka P. Antioxidant effects of coumarins include direct radical scavenging, metal chelation and inhibition of ROS-producing enzymes. Curr Top Med Chem. 2015; 15(5): 415-431.

52. Kalf GF, Schlosser MJ, Renz JF, Pirozzi SJ. Prevention of benzene-induced myelotoxicity by nonsteroidal anti-inflammatory drugs. Environ Health Perspect. 1989; 82: 57-64.

53. Kawahara K, Hohjoh H, Inazumi T, Tsuchiya $\mathrm{S}$, Sugimoto Y. Prostaglandin E2-induced inflammation: Relevance of prostaglandin E receptors. Biochim Biophys Acta. 2015; 1851(4): 414-421.
54. MacEachern L, Laskin DL. Bone marrow phagocytes, inflammatory mediators and benzene toxicity. In: Xenobiotics and Inflammation (Laskin DL, Schook LS, eds). San Diego: Academic Press, 1994; 149-171.

55. Yassine EZ, Dalila B, El MansouriLatifa BS, Lebtar S, Sanae A, Abdellah F. Phytochemical Screening, Anti-inflammatory Activity and Acute Toxicity of Hydro-ethanolic, Flavonoid, Tannin and Mucilage Extracts of Lavandula stoechas L. from Morocco. Int $J$ Pharm Phytochem Res. 2015; 8(1): 31-37.

56. Sourour DA, El Margoushy NM, El Nemr GM. Protective Effects of Vitamin C Against Benzene-Induced Lung Injury in Rats. Med $J$ Cairo Univ. 2012; 80(1): 545-558. 